\title{
Steroid and Growth Hormone Levels in Premature Infants After Prenatal Betamethasone Therapy to Prevent Respiratory Distress Syndrome
}

\author{
PHILIP L. BALLARD, PETER D. GLUCKMAN, GRAHAM C. LIGGINS, SELNA L. KAPLAN, AND \\ MELVIN M. GRUMBACH \\ Department of Pediatrics and the Cardiovascular Research Institute, University of California, San Francisco, \\ California, USA, and Postgraduate School of Obstetrics and Gynecology, University of Auckland, \\ Auckland, New Zealand
}

\begin{abstract}
Summary
Prenatal maternal therapy with glucocorticoid reduces the incidence of respiratory distress syndrome (RDS) in premature infants. To investigate the effects of this treatment on the fetal endocrine system, we determined serum concentrations of betamethasone, cortisol, dehydroepiandrosterone sulfate, growth hormone, and prolactin in cord blood of 215 treated infants and 117 untreated infants of 26-36 wk of gestation. Cortisol levels are suppressed within $6 \mathrm{hr}$ of betamethasone treatment, decrease to $45 \%$ of the concentration in untreated infants $(8.4 \mu \mathrm{g} / \mathrm{dl})$, and return to normal by 7 days. Dehydroepiandrosterone sulfate is reduced maximally by $65 \%$ and returns to normal concentrations (123.5 $\mu \mathrm{g} / \mathrm{dl})$ in $7 \frac{1}{2}$ days. The suppression of both steroids was similar after treatment with $12 \mathrm{mg}$ betamethasone (acetate and phosphate) daily 2 times or with $6 \mathrm{mg}$ betamethasone (alcohol) twice daily 4 times. Peak betamethasone levels were higher after the $12 \mathrm{mg}$ dose, but the two-treatment regimens produced a similar total exposure of the fetus to elevated serum glucocorticoid activity for $2^{1 / 2}$ days and decreased plasma activity for the subsequent $4 \frac{1}{2}$ days. Treated infants with low cortisol concentrations at birth increased their cortisol levels severalfold after birth in response to either intrapartum asphyxia or RDS.

Betamethasone therapy did not affect cord serum prolactin levels, but the concentration of growth hormone was reduced at all gestational ages. The suppression was greatest (53\% decrease) among infants of $28<32 \mathrm{wk}$, and, among older infants, there was a subsequent increase above control levels between 2 and 4 days after treatment.

This study indicates that prenatal betamethasone treatment causes a transient suppression of fetal growth hormone and presumably those pituitary hormones which regulate steroid production by both the definitive and fetal zones of the fetal adrenal. However, the suppression of fetal cortisol does not interfere with the pituitary-adrenocortical response to stress after birth.
\end{abstract}

\section{Speculation}

We speculate that the results of betamethasone treatment on the fetal endocrine system described here may represent only some of the effects which exogenous corticosteroids have on the human fetus. Continuing research in this area will further the understanding of the role of glucocorticoids during development, and will help in establishing the safest and most efficacious treatment regimen for prevention of RDS.

RDS is a major cause of neonatal morbidity and mortality in premature infants. In 1972, Liggins and Howie (24) reported that treatment of women in premature labor with betamethasone significantly lowered the incidence of RDS in their infants. Subsequent reports $(3,4,8,10,14,21,40)$ have confirmed this effect, and prenatal steroid therapy to prevent RDS is now used routinely in many centers.

Although the efficacy of this treatment is now established, there is relatively little information available regarding the effects of treatment on the fetal endocrine system. In a previous report from this laboratory (7), the levels of betamethasone and cortisol in both maternal and cord serum after therapy were described. In the present study, we have assayed additional cord samples to define further the effect of betamethasone on steroid and other hormone levels. We report here the effect of this therapy on cortisol, dehydroepiandrosterone sulfate (DHEAS), growth hormone, and prolactin in cord serum. In addition, we compare the unbound plasma glucocorticoid activity in two regimens of betamethasone therapy, and also examine cortisol levels in newborn infants exposed to neonatal stress.

\section{METHODS}

\section{TREATMENT OF PATIENTS}

Women in premature labor admitted to the University of California, San Francisco, to Mount Zion Hospital, San Francisco, and to National Womens' Hospital, Auckland, New Zealand, received, with their consent, treatment with a mixture of $6 \mathrm{mg}$ betamethasone phosphate and $6 \mathrm{mg}$ betamethasone acetate. A second dose was given 12-24 hr later if delivery had not occurred. The 127 infants of these women are designated $12 \mathrm{mg}$ group. A second group of women at National Womens' Hospital received $6 \mathrm{mg}$ of betamethasone alcohol as part of a clinical trial. This dose was repeated 3 times at 12 -hr intervals unless delivery occurred. Infants of women receiving this therapy are designated $6 \mathrm{mg}$ group (88 infants). A third group of 117 infants (untreated group) were born during the same period of time (1972-1977) but received either no prenatal steroid therapy or placebo treatment as controls for the $12 \mathrm{mg}$ group $(4,24)$.

Clinical data for many infants of the untreated and $12 \mathrm{mg}$ groups have been previously presented $(4,7,24)$. All three groups are comprised of live, inborn infants of 26-36 wk of gestational age without congenital malformations incompatible with life. The management of patients and the collection of mixed or umbilical venous cord bloods have been described $(4,7,24)$. Because of limited volumes, not all hormone assays were performed on each sample of cord serum. Infant gestational age was assessed both by obstetrical data and by physical and neurologic development, and RDS was diagnosed as previously described $(4,24)$. Intrapartum asphyxia was defined as an Apgar score of less than 5 at $1 \mathrm{~min}$ and/or less than 7 at $5 \mathrm{~min}$. 


\section{HORMONE ASSAYS}

Serum betamethasone levels were determined using the glucocorticoid radioreceptor assay which was performed exactly as previously described $(6,7)$. Cortisol levels were determined using the corticosteroid binding globulin (CBG)-isotope method of Murphy (28). This method measures both corticosterone and cortisol, the predominant glucocorticoid in human cord blood, but does not detect betamethasone ( $<1 \%$ the activity of cortisol) $(6)$. Before ethanol extraction, serum samples were washed twice at 15 -min intervals with 20 volumes of petroleum ether by vortexing in 5 -sec bursts for $30 \mathrm{sec}$. It was found that this washing procedure, which was somewhat more extensive than previously used (7), removes more than $95 \%$ of the progesterone and results in somewhat lower values for serum cortisol than previously reported in this laboratory. Data in Figures 1 and 2 include some specimens which were included in a previous report (7), and these samples have been reassayed using the wash procedure described previously in this paper. Studies of cortisol levels after birth utilized residual heparinized plasma obtained for determination of blood gas values. Such samples were obtained as frequently as every $10 \mathrm{~min}$ during the first $2 \mathrm{hr}$ of life, and approximately every other hr thereafter through the first 2 days of life.

The percent of serum cortisol bound to CBG was determined by the charcoal method as previously described (7). Serum albumin levels were determined by the dye-binding method of Doumas et al. (13), and the amount of cortisol bound by albumin was calculated (39). In an analysis of cord blood specimens from 43 untreated infants and 40 treated infants, the mean percent of unbound cortisol increased linearly from $22.1 \%$ at a total cortisol concentration of $3 \mu \mathrm{g} / \mathrm{dl}$ to $28.2 \%$ at a level of $10 \mu \mathrm{g} / \mathrm{dl}$.

DHEAS was determined by radioimmunoassay (9); the sensitivity in this assay is $44 \mathrm{pg}$ and the interassay coefficient of variation is $14.1 \%$. The antiserum to DHEAS does not crossreact significantly with 16-OH DHEAS (9). Growth hormone was measured by radioimmunoassay using NIH-HGH-2160E as the standard (43). The sensitivity of this assay is $0.01 \mathrm{ng}$ and the interassay variation is $6.0 \%$. Prolactin was determined by radioimmunoassay using Lewis HPRL \#2 as the standard $(1,17)$. The assay has a sensitivity of $0.03 \mathrm{ng}$ and an interassay variation of $9.0 \%$.

Statistical significance was evaluated by Student's unpaired $t$ test and by the least squares method of regression analysis. Values are presented as mean $\pm \mathrm{SE}$.

\section{RESULTS}

\section{CORTISOL CONCENTRATION IN CORD SERUM OF THE 12 MG GROUP}

Figure 1 shows individual values for cortisol in 41 infants delivered within $20 \mathrm{hr}$ after the first maternal dose of $12 \mathrm{mg}$ of betamethasone. Values for 84 infants of the untreated group with the same gestational age distribution are shown for comparison; we found no significant trend in cortisol concentration in untreated infants between 26 to $36 \mathrm{wk}$ of gestation. There is a trend toward lower cord cortisol concentrations in treated infants within a few $\mathrm{hr}$ of the dose of betamethasone. The mean level for samples collected between $6-16 \mathrm{hr}$ was $3.7 \pm 0.47 \mu \mathrm{g} / \mathrm{dl}$, a significant $(P$ $<0.001$ ) reduction from the mean value of $8.4 \pm 0.44$ $\mu \mathrm{g} / \mathrm{dl}$ for the untreated group. The mean value for the 10 samples between 17 to $20 \mathrm{hr}$ after betamethasone treatment was $5.8 \pm 1.0$ ( $P=0.05$ compared with untreated group), representing an apparent upward trend during this interval.

Figure 2 presents a similar analysis for 86 additional infants of the $12 \mathrm{mg}$ group who delivered at various times after the second dose of $12 \mathrm{mg}$ of betamethasone. No differences between infants receiving the second dose at 12,18 , or $24 \mathrm{hr}$ after the first dose were noted. The $Y$ intercept of the regression line yields a cortisol concentration of $3.8 \mu \mathrm{g} / \mathrm{dl}$ immediately after the second dose of betamethasone. By this analysis, cortisol returns to the untreated level approximately 7 days after betamethasone treatment.
We were able to examine cortisol concentrations at various times after birth in two infants of the $12 \mathrm{mg}$ group who had uneventful neonatal courses. One infant $(1100 \mathrm{~g}, 28 \mathrm{wk}$ of gestation) delivered $18 \mathrm{hr}$ after a second dose of betamethasone, and the other infant ( $1495 \mathrm{~g}, 31 \mathrm{wk}$ ) was born $9 \mathrm{hr}$ after betamethasone therapy. Cortisol concentrations were 3.1 and $1.6 \mu \mathrm{g} / \mathrm{dl}$ at birth and remained at or below the cord value for 30 and $13 \mathrm{hr}$ after birth, respectively. Cortisol was within the normal range (7.9-11.0 $\mu \mathrm{g} / \mathrm{dl}, \mathrm{n}=4)$ between 55 and $94 \mathrm{hr}$ after birth in the first infant, and in the second infant remained low $(3.7-4.4 \mu \mathrm{g} / \mathrm{dl})$ between $21-41 \mathrm{hr}$ after birth in the last three samples available. These findings suggest that the recovery pattern for cortisol after birth in

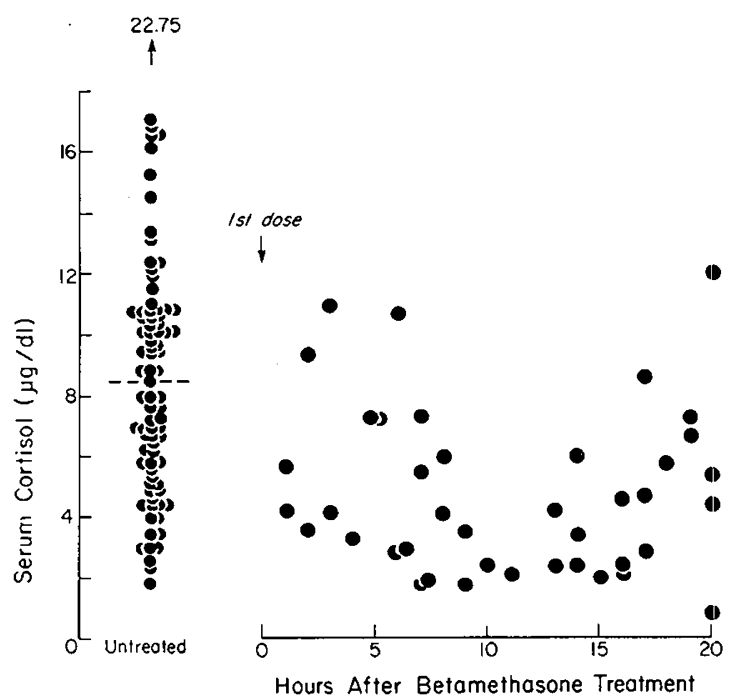

Fig. 1. Cortisol levels in cord serum of infants delivering within $20 \mathrm{hr}$ of the first maternal dose of $12 \mathrm{mg}$ betamethasone. Individual data are shown for 41 treated infants (12 $\mathrm{mg}$ group) and 84 untreated infants with mean gestational ages of $31.9 \pm 0.46$ and $31.6+0.31 \mathrm{wk}$, respectively. The mean cortisol level (-- ) for the untreated group is $8.4 \pm 0.44 \mu \mathrm{g} / \mathrm{dl}$.

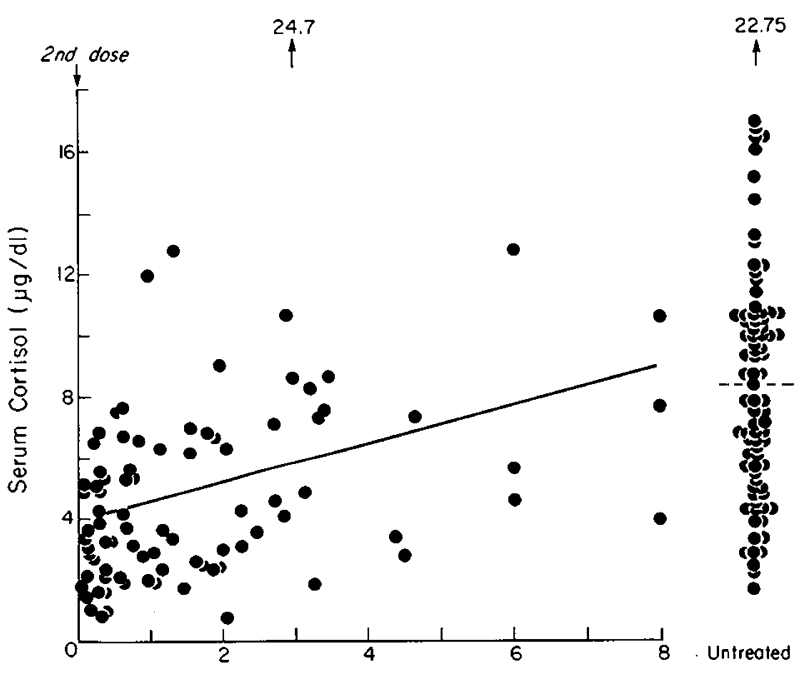

Days After Betomethasone Treatment

Fig. 2. Cortisol levels in cord serum of infants delivering at various times after the second maternal dose of $12 \mathrm{mg}$ betamethasone. Data for 86 treated infants of $12 \mathrm{mg}$ group (mean gestational age $31.1 \pm 0.26 \mathrm{wk}$ ) and 84 untreated infants (mean age $31.6 \pm 0.31 \mathrm{wk}$ ) are shown. The mean cortisol value for the untreated group is $8.4 \pm 0.44 \mu \mathrm{g} / \mathrm{dl}$. The arrows indicate values off scale. The regression line equation is $\mathrm{Y}=3.8 \pm 0.64 \mathrm{X}$ with $r=0.34(P<0.01)$. 
the unstressed infant is similar to that occurring in utero. In a later section cortisol levels after birth in the stressed newborn infant are discussed.

\section{BETAMETHASONE AND CORTISOL IN CORD SERUM OF THE 6 MG GROUP}

In a separate trial of steroid therapy, four maternal injections of $6 \mathrm{mg}$ of betamethasone (alcohol) were given every $12 \mathrm{hr}$. Figure 3 presents data for both betamethasone and cortisol levels in 88 infants who delivered at various times after treatment with this 6 mg regimen. In this analysis, data were grouped by $12-$ to $48-\mathrm{hr}$ intervals to allow comparison of the synthetic and endogenous steroid levels. During the first $48 \mathrm{hr}$, betamethasone levels ranged between 2.0-17.4 $\mu \mathrm{g}$ cortisol equivalents/dl, with mean levels of $7.0,9.4,8.5$, and $7.7 \mu \mathrm{g} / \mathrm{dl}$ at $8.5,18.8,31.6$, and $41.3 \mathrm{hr}$, respectively. These times represent the mean time for the samples available after each dose of steroid. Betamethasone was not detected in any samples obtained beyond $60 \mathrm{hr}$ of the last dose.

Cortisol levels are significantly suppressed by $24-36 \mathrm{hr}(4.1 \pm$ $1.39 \mu \mathrm{g} / \mathrm{dl})$ and reach their lowest levels between $36-48 \mathrm{hr}(3.6 \pm$ $0.48 \mu \mathrm{g} / \mathrm{dl}, P<0.005$ compared to the untreated group. Cortisol then increases in an inverse relationship to the concentration of betamethasone, returning to the untreated level by approximately 6 days. For this group of infants, there was no apparent correlation between either cortisol or betamethasone levels and the occurrence of RDS (11 infants).

\section{COMPARISON OF SERUM UNBOUND GLUCOCORTICOID ACTIVITY IN THE 12 MG AND 6 MG GROUPS}

In Figure 4, we have calculated the approximate levels of serum unbound glucocorticoid activity (i.e., betamethasone + cortisol) in serum of infants exposed to the $12 \mathrm{mg} v s$. the $6 \mathrm{mg}$ betamethasone regimen. Betamethasone levels after the $12 \mathrm{mg}$ dose are taken from a previous study (7). With the $12-\mathrm{mg}$ regimen, unbound glucocorticoid activity is maximal $\mathrm{l} \mathrm{hr}$ after the first injection at a level of $8.8 \mu \mathrm{g} / \mathrm{dl}$, a 4 -fold increase over the preinjection (untreated) level of $2.2 \mu \mathrm{g} / \mathrm{dl}$. Calculated by $6-\mathrm{hr}$ intervals, the level falls to $3.9 \mu \mathrm{g} / \mathrm{dl}$ at $18 \mathrm{hr}$ and then increases to 7.9 after the second dose. By $60 \mathrm{hr}$, betamethasone has been cleared, and the unbound corticoid activity falls below the untreated level to $1.2 \mu \mathrm{g} / \mathrm{dl}$, reflecting the suppression of endogenous cortisol. This is followed by a rise to preinjection levels by about 7 days.

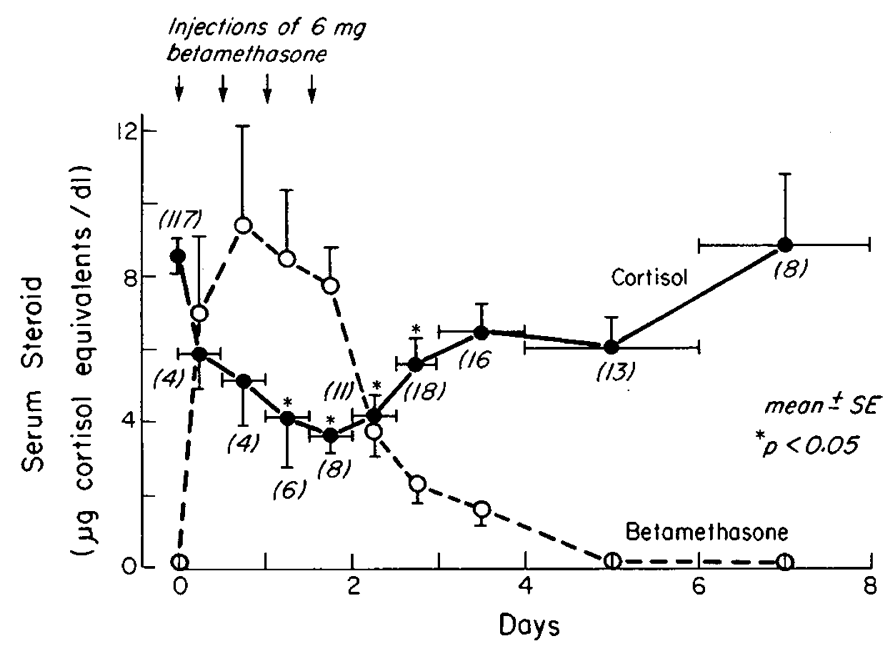

Fig. 3. Mean cortisol and betamethasone levels in infants who delivered at various times after their mothers were treated with $6 \mathrm{mg}$ betamethasone. Data are shown for 88 treated infants (6 mg group) and 117 infants of the untreated group (time zero, mean value $8.5 \pm 0.42 \mu \mathrm{g} / \mathrm{dl}$ ). The mean gestational age was $32.7 \pm 0.6 \mathrm{wk}$ for the $6 \mathrm{mg}$ group and 32.7 $\pm 0.27 \mathrm{wk}$ for the untreated group. Regression analysis of the cortisol data (not shown) gave the equation $\mathrm{Y}=4.2+0.72 \times(r=0.38, P<0.01)$.

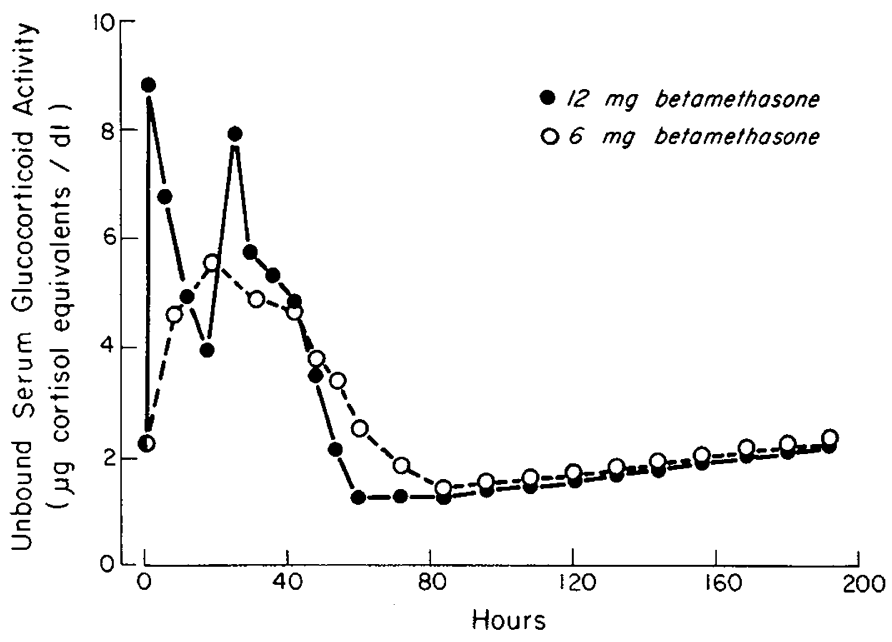

Fig. 4. Unbound glucocorticoid activity in serum of infants exposed to $12 \mathrm{mg}$ and $6 \mathrm{mg}$ betamethasone regimens. Levels at various times after treatment were estimated using data in Figures 1-3 and in Reference 7. Unbound betamethasone is assumed to be $47 \%$ of the total level (7) and the percentage of cortisol unbound was determined by the charcoal assay and consideration of albumin binding as described in Methods.

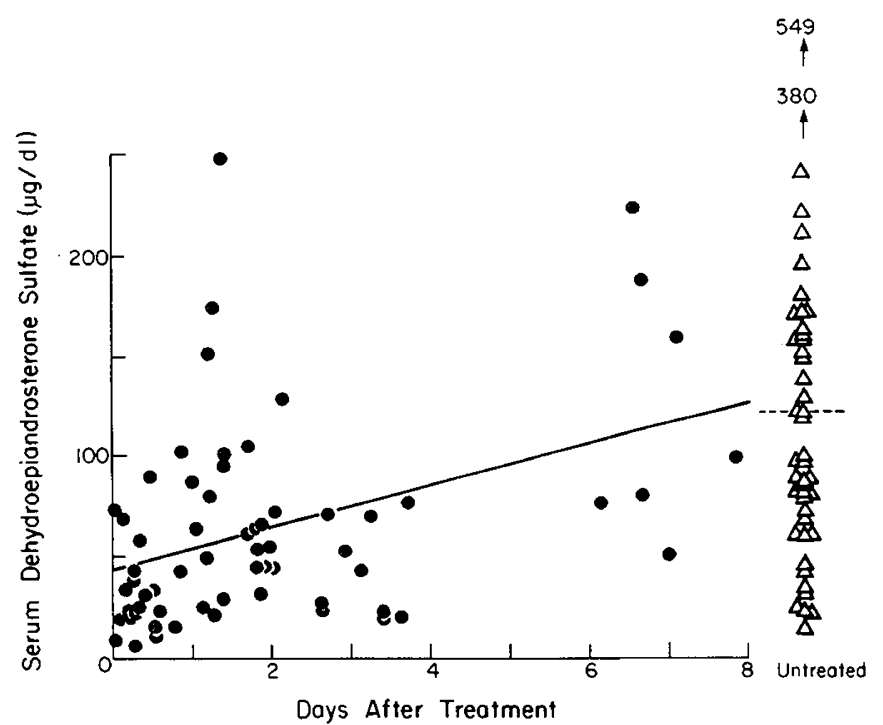

Fig. 5. DHEAS concentrations in cord serum of infants delivering at various times after exposure to $6 \mathrm{mg}$ doses of betamethasone. Data for 64 infants of the $6 \mathrm{mg}$ group treated for $>24 \mathrm{hr}$ are plotted as the time from the last injection to delivery. The regression equation is $\mathrm{Y}=43.3+10.5$ $\mathrm{X}$ with $r=0.45(P<0.01)$. The DHEAS level in 45 untreated infants is $123.5 \pm 14.3 \mu \mathrm{g} / \mathrm{dl}$. The mean gestational age for the $6 \mathrm{mg}$ group and untreated group was $33.3 \pm 0.3$ and $33.1 \pm 0.38 \mathrm{wk}$, respectively.

For the 6-mg betamethasone regimen, the data were calculated for $12-\mathrm{hr}$ intervals, because fewer samples were available. It is apparent from Figure 4 that the mean level of unbound corticoid activity during the first 2 days of treatment is similar for the two treatment schedules. As with the 12 -mg regimen, serum glucocorticoid activity falls below the preinjection level before eventually returning to normal. Thus, the two treatment protocols that have been compared seem to give a similar pattern of fetal exposure to elevated and, subsequently, suppressed corticoid levels.

\section{DHEAS CONCENTRATION IN CORD SERUM OF THE 6 MG GROUP}

It was of interest to examine the effect of betamethasone therapy on the levels of DHEAS, the major steroid secreted by the fetal 
zone of the adrenal. Figure 5 presents data from 64 infants treated with $6 \mathrm{mg}$ doses of betamethasone who delivered at various times (at least $24 \mathrm{hr}$ ) after treatment. By regression analysis, the steroid levels are significantly depressed with a value at the $\mathrm{Y}$ intercept of $43.3 \mu \mathrm{g} / \mathrm{dl} v s$. a level of $123.5 \pm 14.3 \mu \mathrm{g} / \mathrm{dl}$ in 45 untreated infants of a similar gestational age distribution. In data not shown, we found, as did Noguchi et al. (31), no effect of gestational age on cord levels of DHEAS in 52 untreated infants between 26 to 40 wk of gestation. For treated infants, DHEAS concentrations re-
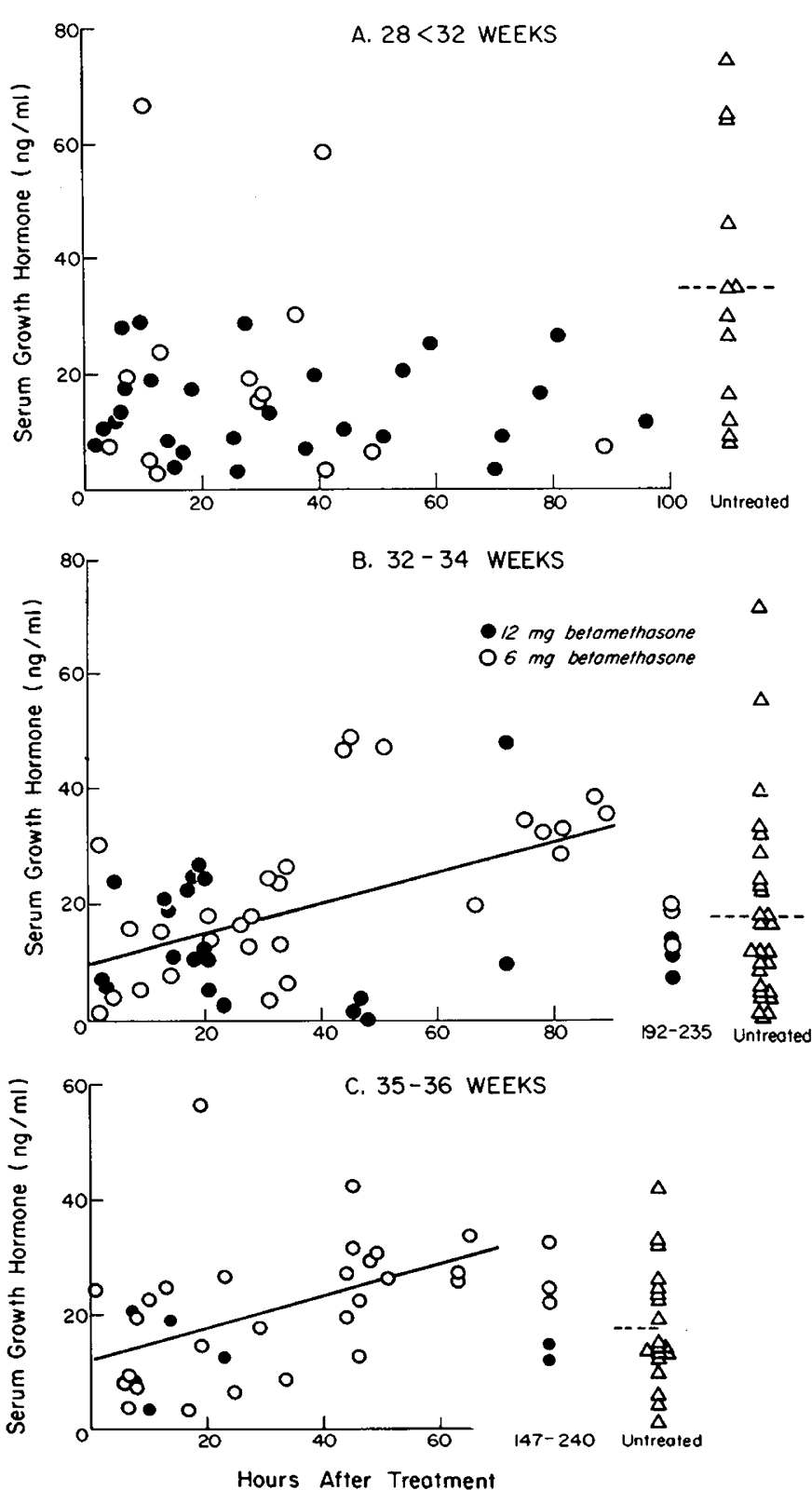

Fig. 6. Growth hormone levels in cord serum of infants delivered at various times after maternal treatment with either $6 \mathrm{mg}$ or $12 \mathrm{mg}$ betamethasone. A) Infants of gestational age $28<32$ wk. Data for 42 treated infants are plotted as hr after last dose of steroid; the mean level is 15.9 $\pm 2.05 \mathrm{ng} / \mathrm{ml}$ for all treated infants vs. $34.9 \pm 6.7 \mathrm{ng} / \mathrm{ml}(P<0.001)$ for 12 untreated infants of the same gestational age. Two additional infants (not shown) had levels of 63.3 and $46.7 \mathrm{ng} / \mathrm{ml}$ at 108 and $192 \mathrm{hr}$ after treatment, respectively. B) Infants of gestational age 32-34 wk. Data for 48 treated infants and 27 untreated infants (mean $17.9 \pm 1.92 \mathrm{ng} / \mathrm{ml}$ ) are shown. The regression equation is $\mathrm{Y}=10.3+0.26 \mathrm{X}$ with $r=0.5(P<$ 0.01 ). C) Infants of gestational age 35 and 36 wk. Data for 37 treated infants and 19 untreated infants (mean $17.8 \pm 2.4 \mathrm{ng} / \mathrm{ml}$ ) are shown. The regression equation is $\mathrm{Y}=12.2+0.28 \mathrm{X}$ with $r=0.46(P<0.01)$.
Table 1. Cortisol levels in premature infants exposed to neonatal stress

\begin{tabular}{|c|c|c|c|}
\hline \multirow[b]{2}{*}{ Stress } & \multicolumn{2}{|c|}{ Serum Cortisol $(\mu \mathrm{g} / \mathrm{dl})$} & \multirow[b]{2}{*}{$P$} \\
\hline & $\begin{array}{l}\text { Betamethasone- } \\
\text { treated infants }\end{array}$ & $\begin{array}{l}\text { Untreated } \\
\text { infants }\end{array}$ & \\
\hline Intrapartum asphyxia' (n) & (14) & (19) & \\
\hline Level at birth & $3.3 \pm 0.43$ & $7.3 \pm 0.71$ & $<0.05$ \\
\hline Mean level at $1-2 \mathrm{hr}^{2}$ & $8.2 \pm 1.23$ & $14.8 \pm 1.85$ & $<0.05$ \\
\hline RDS (n) & (13) & (15) & \\
\hline Level at birth & $4.0 \pm 0.60$ & $7.0 \pm 0.78$ & $<0.05$ \\
\hline Peak level in first 2 days $^{3}$ & $22.4 \pm 3.72$ & $30.0 \pm 2.88$ & NS \\
\hline
\end{tabular}

${ }^{1}$ Mean \pm SE Apgar scores at 1 and 5 min were $1.6 \pm 0.3$ and $5.2 \pm 0.9$, respectively, for betamethasone-treated infants, and $1.6 \pm 0.2$ and $5.6 \pm$ 0.4 , respectively, for untreated infants.

${ }^{2}$ Mean value for $2-4$ determinations.

${ }^{3}$ Maximal value found in serial determinations.

turned to the untreated level by about $7 \frac{1}{2}$ days after the last dose of betamethasone.

\section{GROWTH HORMONE CONCENTRATION IN CORD SERUM}

Figure 6 presents data for the level of growth hormone in cord serum of infants exposed to either $12 \mathrm{mg}$ or $6 \mathrm{mg}$ betamethasone treatment. Because growth hormone levels decline during the last trimester (20), the data are presented by intervals of gestational age. For 42 treated infants of $28<32$ wk of gestation (Fig. 6A), the mean level was $15.9 \pm 2.05 \mathrm{ng} / \mathrm{ml}$ which was significantly less $(P$ $<0.001$ ) than the level of $34.9 \pm 6.6 \mathrm{ng} / \mathrm{ml}$ in 12 untreated infants. With the possible exception of two high values in infants receiving $6 \mathrm{mg}$ betamethasone, there was no apparent difference in values between infants of the 6 and the $12 \mathrm{mg}$ groups. There was no significant regression $(r=0.04)$ for the interval between $0-100 \mathrm{hr}$ after treatment. Two additional infants (not shown) had concentrations within the normal range $(63.3$ and $46.7 \mathrm{ng} / \mathrm{ml})$ at 108 and $192 \mathrm{hr}$, respectively.

Fig. 6B shows a similar analysis of growth hormone for infants of 32-34 wk of gestation. The mean level for treated infants was not significantly different from the untreated group. However, a significant regression was noted for these data, suggesting suppression of growth hormone levels shortly after treatment with an increase by $80-90 \mathrm{hr}$ to higher values. Six infants delivering 192$235 \mathrm{hr}$ after treatment showed values within the normal range.

A similar pattern is found for growth hormone in treated infants of 35 to 36 wk of gestation (Fig. 6C). Although the mean concentration was not significantly different from the untreated value, the regression line intercepts the $Y$ axis at a value of 12.2 compared with the mean level in the untreated infants of 17.8. Most values in infants $40 \mathrm{hr}$ after treatment are above the mean for the untreated infants, while five samples obtained 147-240 hr after treatment are within the normal range.

\section{PROLACTIN CONCENTRATION IN CORD SERUM}

We also looked for an effect of betamethasone therapy on the concentration of cord prolactin. Because RDS in premature infants is associated with lower prolactin concentrations in cord serum (17), analysis was limited to infants without RDS. Prolactin concentrations in infants who delivered $<8$ days after therapy (both 6 and $12 \mathrm{mg}$ groups) of $28<32$ and $32<35 \mathrm{wk}$ of gestation were $72.6 \pm 10.07 \mathrm{ng} / \mathrm{ml}(\mathrm{n}=22)$ and $134.5 \pm 10.5 \mathrm{ng} / \mathrm{ml}(\mathrm{n}=$ 54), respectively; corresponding values in the untreated group were $75.5 \pm 33 \mathrm{ng} / \mathrm{ml}(\mathrm{n}=7)$ and $161.8 \pm 18.9 \mathrm{ng} / \mathrm{ml}(\mathrm{n}=23)$. The mean prolactin concentrations for treated infants were not significantly different from the untreated populations, and there was no trend in serum levels associated with the interval after therapy. 
CORTISOL LEVELS IN RESPONSE TO STRESS AFTER BIRTH

To evaluate the responsiveness of the pituitary-adrenal axis in treated infants, we determined cortisol levels after birth in infants who were stressed by either intrapartum asphyxia or RDS (Table 1). All of these treated infants delivered within $60 \mathrm{hr}$ of maternal treatment with $12 \mathrm{mg}$ of betamethasone, and all had suppressed cortisol levels at birth. Cortisol increased after birth in 13 of 14 treated infants with asphyxia and in all untreated asphyxiated infants. The increment in cortisol concentration was $4.9 \mu \mathrm{g} / \mathrm{dl}$ for treated infants and $7.5 \mu \mathrm{g} / \mathrm{dl}$ for untreated infants (NS). Cortisol levels increased during the first 2 days of life in all infants who developed RDS. The increment in cortisol concentration was 18.4 $\mu \mathrm{g} / \mathrm{dl}$ for treated infants and $23 \mu \mathrm{g} / \mathrm{dl}$ for untreated babies (NS). A similar pattern of increase occurred in both groups; the mean time for obtaining highest values was 25 and $20.2 \mathrm{hr}$ in treated and untreated infants, respectively.

\section{DISCUSSION}

Previous reports from this laboratory $(5,7)$ and elsewhere $(16$, 34,38 ) indicated that prenatal steroid therapy reduces the concentration of cortisol in cord blood to $24-46 \%$ of control levels. The present report further defines this suppression. Fetal cortisol concentrations begin to decrease within approximately $6 \mathrm{hr}$ of the first dose of $12 \mathrm{mg}$ betamethasone and are lowest immediately after the second dose. The unbound cortisol concentration at this time is $0.9 \mu \mathrm{g} / \mathrm{dl}$ compared to $2.2 \mu \mathrm{g} / \mathrm{dl}$ in untreated infants, indicating a reduction of $59 \%$. Cortisol begins to increase by $24 \mathrm{hr}$ after treatment and is within the normal range by 7 days. The decrease in fetal cortisol with $6 \mathrm{mg}$ betamethasone is somewhat slower, but the degree of suppression and recovery rate are similar to that with the $12 \mathrm{mg}$ dose.

These results for cord blood differ from those reported for the maternal circulation in which cortisol concentrations decrease to $10 \%$ of preinjection levels and return to normal by 3 days after the last dose of betamethasone $(7,24,30)$. The greater suppression in maternal serum is consistent with the 3-fold higher concentrations of betamethasone in the mother (7). Betamethasone is not detected in either maternal or cord serum by 2 days after the dose (7), suggesting that the slower increase in cortisol concentrations in the fetus is due to a slower recovery of fetal pituitary-adrenal function rather than longer exposure to synthetic steroid. It is also possible that serum levels of glucocorticoid do not accurately reflect levels in the pituitary (and other tissues) of the fetus.

Infants receiving prenatal therapy also had lower serum concentrations of DHEAS. Cord levels after the second dose of betamethasone were $35 \%$ of controls, and recovery occurred at the same rate as for fetal cortisol. A similar suppression of cord DHEAS in term infants after prenatal cortisol treatment is reported by Simmer et al. (36). The findings thus indicate that there is a similar pattern of suppression and recovery of steroids produced by both the definitive and fetal zones of the fetal adrenal. This suggests that betamethasone suppresses pituitary hormone(s) which regulate both zones of the fetal adrenal.

It has been reported that maternal plasma concentrations of estrone (32), $17 \beta$-estradiol $(30,32)$, and estriol (30) all decrease with prenatal betamethasone treatment. Levels decrease to 29$38 \%$ of control and return to the normal range by 6 or more days after the last injection. The similar degree of suppression and rate of recovery of DHEAS reported above is consistent with the precursor role of this fetal steroid in the synthesis of estrogens within the placenta.

The suppression of fetal and newborn cortisol levels associated with betamethasone treatment raised the question of adrenocortical responsiveness in the neonatal period. Among 27 treated premature infants with low cortisol concentrations at birth, cortisol increased in all infants except one in response to the stress of asphyxia or RDS. The one infant without an increase in cortisol was transiently asphyxiated at birth (Apgar score of 1 and 9). This male infant ( 28 wk of gestation and $1100 \mathrm{~g}$ ) did well clinically and had normal cortisol concentrations by the 3rd day of life as described above. Sybulski (38) also noted a rise in plasma cortisol in 2 treated infants with RDS, and Ohrlander et al. (33) demonstrated an increase of cortisol after injection of ACTH to infants who delivered $<1$ wk after betamethasone treatment. These combined results indicate that prenatal betamethasone therapy does not interfere with the premature infant's adrenocorticol response to stress after birth.

The original protocol of Liggins and Howie (24) for prophylactic steroid therapy utilized injection of $6 \mathrm{mg}$ betamethasone phosphate and $6 \mathrm{mg}$ betamethasone acetate given twice $24 \mathrm{hr}$ apart. In an attempt to define the optimal treatment regimen, a trial of more frequent injections of a lower dose of betamethasone $16 \mathrm{mg}$ every $12 \mathrm{hr}$ ) has been carried out by Liggins. It was found that the concentrations of betamethasone after $6 \mathrm{mg}$ of betamethasone alcohol are generally lower than observed with $12 \mathrm{mg}$ of the phosphate and acetate forms (7). From planimetry analysis of the data of Figure 4, it was estimated that the $6 \mathrm{mg}$ dose provides the fetus at least $75 \%$ of the unbound serum glucocorticoid activity obtained with the $12-\mathrm{mg}$ regimen; the total time that the fetus is exposed to elevated levels is also similar. Assuming that the response of the fetal lung is approximately proportional to the concentration of unbound serum steroid within the ranges of glucocorticoid activity encountered here, we would predict similar effectiveness of the $6 \mathrm{mg}$ and $12 \mathrm{mg}$ betamethasone protocols in prevention of RDS.

Steroid-induced lung development may be a reversible process in very small infants (23). A longer treatment interval might improve the outcome for infants that are not delivered within $2 \frac{1}{2}$ days of the first dose of betamethasone, because infants remaining in utero beyond this time are exposed to lower levels of serum glucocorticoid activity than before treatment. However, the possible benefits of more prolonged therapy, such as used by Caspi et al. (10), must be weighed against the possible hazards of a longer exposure to elevated steroid levels.

An unexpected finding in this study was the lower concentration of growth hormone in cord blood of treated infants. Suppression was evident within a few hr of steroid treatment, but the extent and course of the effect varied with gestational age. The mean growth hormone concentration in infants of $28<32$ wk was suppressed by $54 \%$ compared with maximal suppression of 43 and $32 \%$ in the older groups. No upward trend occurred within $100 \mathrm{hr}$ of the betamethasone dose in the $28<32$ wk group, while a significant positive regression was evident over the same period in older infants. In addition, there is an apparent rebound of hormone concentrations above normal in the larger infants.

Glucocorticoids suppress growth hormone secretion in adults during insulin-induced hypoglycemia $(15,18,29)$ and during sleep (27). The degree of suppression is related to both the dose and duration of steroid treatment $(15,41)$. However, children appear to be less sensitive to suppression of growth hormone by both exogenous and endogenous glucocorticoids $(26,35,37)$. The present study provides evidence that glucocorticoids can suppress growth hormone during fetal life. Unlike the effect of glucocorticoids seen in adults, betamethasone therapy of the fetus suppresses the basal concentration of growth hormone. The degree of suppression was greater in the less mature infants who had higher concentrations of growth hormone, and the suppression appeared to be more persistent in these infants. The higher growth hormone concentrations of the fetus compared to the adult are not due to differences in metabolic clearance rate, (12), but have been postulated to result from immaturity of hypothalamic regulation of growth hormone secretion $(19,20)$. The ability of glucocorticoids to suppress growth hormone in the fetus but not in the child may result from this immaturity of hypothalamic regulation of fetal growth hormone secretion.

The transient decrease in serum growth hormone after prenatal steroid therapy is unlikely to be physiologically important for the fetus. Growth hormone is apparently not essential for growth of the human fetus; infants born with familial growth hormone 
deficiency or with pituitary agenesis have a normal length at birth $(22,25)$. While neonatal growth hormone deficiency has been associated with hypoglycemia (25), there have been no reports of an increased incidence of hypoglycemia in newborn infants who received prenatal glucocorticoid therapy (3).

As noted in this study and previously $(2,17,42)$, prolactin concentrations in cord serum increase during the third trimester. Whereas glucocorticoid treatment of adults is reported to suppress both basal prolactin concentrations and prolactin release after hypoglycemia (11), it was found in the present study that fetal prolactin levels were not affected by betamethasone administration.

\section{REFERENCES AND NOTES}

1. Aubert. M. L.. Grumbach, M. M. and Kaplan, S. L.: Heterologous radioimmunoassay for plasma human prolactin (hPRL): Values in normal subjects. puberty, pregnancy and in pituitary disorders. Acta Endocrinol., 77: 460 (1974).

2. Aubert, M. L., Grumbach, M. M. and Kaplan, S. L.: The ontogenesis of human fetal hormones. III. Prolactin. J. Clin. Invest., 56: 155 (1975).

3. Ballard, R. A., and Ballard, P. L.: Use of prenatal glucocorticoid therapy to prevent respiratory distress syndrome. A supporting view. Am. J. Dis. Child., 130: 982 (1976).

4. Ballard, R. A., Ballard, P. L., Granberg, J. P., and Sniderman, S.: Prenatal administration of betamethasone for prevention of respiratory distress syndrome. J. Pediatr., 94: 97 (1978).

5. Ballard, P. L., Gluckman, P. D., Liggins, G. C.. Kaplan, S. L. and Grumbach, M. M.: Betamethasone (Beta) therapy for prevention of respiratory distress syndrome (RDS): Effects on fetal hormone levels. Clin. Res. (Abstract), 27: 122A (1979).

6. Ballard, P. L.. Carter, J. P.. Graham, B. S., and Baxter, J. D.: A radioreceptor assay for evaluation of the plasma glucocorticoid activity of natural and synthetic steroids in man. J. Clin. Endocrinol. Metab., 41: 290 (1975).

7. Ballard, P. L., Granberg, P., and Ballard, R. A.: Glucocorticoid levels in maternal and cord serum after prenatal betamethasone therapy to prevent respiratory distress syndrome. J. Clin. Invest., 56: 1548 (1975).

8. Block, M. F., Kling, O. R., and Crosby, W. M.: Antenatal glucocorticoid therapy for the prevention of respiratory distress syndrome in the premature infant. Obstet. Gynecol., 50: 186 (1977).

9. Buster, J. E., and Abraham, G. E.: Radioimmunoassay of dehydroepiandrosterone sulphate. Anal. Lett. 5: 543 (1972).

10. Caspi, E., Schreyer, P.. Weinraub, Z., Reif, R., Levi, I., and Mundel, G. Prevention of the respiratory distress syndrome in premature infants by antepartum glucocorticoid therapy. Br. J. Obstet. Gynaecol., 83: 187 (1976).

11. Copinschi, G., L'Hermite, M., Leclercq. R., Goldstein, J., Vanhaelst, L., Virasoro, E., and Robyn, C.: Effects of glucocorticoids on pituitary hormonal responses to hypoglycemia. Inhibition of prolactin release. J. Clin Endocrinol. Metab. 40: 442 (1975).

12. Cornblath, M., Parker, M. L., Reisner, S. H., Forbes. A. E., and Daughaday, W $H$.: Secretion and metabolism of growth hormone in premature and full term infants. J. Clin. Endocrinol. Metab., 25: 209 (1965).

13. Doumas, B. T. Watson, W. A., and Biggs, H. G.: Albumin standards and the measurement of serum albumin with bromcresol green. Clin. Chem. Acta, 31: $87(1971)$

14. Fargier, P., Salle, B., Baud, M., Gagnaire, J. C., Arnaud, P., and Magnin, P.: Prevention du syndrome de detresse respiratoire chez la premature. Nouv. Presse Med.. 3: 1595 (1974).

15. Frantz, A. G., and Rabkin, M. T.: Human growth hormone: clinical measurement, response to hypoglycemia and suppression by glucocorticoids. N. Engl. J. Med., 27I: 1375 (1964).

16. Gennser, G., Ohrlander. S.. and Eneroth. P.: Cortisol in amniotic fluid and cord blood in relation to prenatal betamethasone load and delivery. Am. J. Obstet. Gynecol., 124: 43 (1976).

17. Gluckman, P. D., Ballard, P. L., Kaplan, S. L., Liggins, G. C., and Grumbach M. M.: Prolactin in umbilical cord blood and the respiratory distress syndrome. J. Pediatr., 93: 1011 (1978)

18. Hartof, M.. Gaafar. M. A.. and Fraser. R.: Effects of corticosteroids on serum growth hormone. Lancet, 2: 376 (1966).

19. Kaplan, S. L., Grumbach, M. M., and Aubert, M. L.: The ontogenesis of pituitary hormones and hypothalamic factors in the human fetus: maturation of central nervous system regulation of anterior pituitary function. Rec. Prog. Horm. Res.. 32: 161 (1976).

20. Kaplan, S. L., Grumbach, M. M., and Shepard, T. H.: The ontogenesis of human fetal hormones. 1. Growth hormone and insulin. J. Clin. Invest., 51: 3080 (1972).

21. Kennedy, J. L., Jr.: Prenatal glucocorticoid treatment: Prevention of respiratory distress syndrome. In: T. D. Moore: Lung maturation and the Prevention of Hyaline Membrane Disease. Report of the Seventieth Ross Conference on Pediatric Research. Ross Laboratories, Columbus, Ohio, pp. 105-110. (1976).
22. Liggins, G. C.: The influence of the fetal hypothalamus and pituitary on growth. In: K. Elliot and J. Knight: Size at Birth. (Elsevier-Excerpta Medica, North Holland, Amsterdam, 1974) pp. 165-182.

23. Liggins, G. C.: Prenatal glucocorticoid treatment: Prevention of respiratory distress syndrome. In: T. D. Moore: Lung Maturation and Prevention of Hyaline Membrane Disease. Report of the Seventieth Ross Conference on Pediatric Research. (Ross Laboratories, Columbus, Ohio, 1976) pp. 97-103.

24. Liggins, G. C.. and Howie, R. N.: A controlled trial of antepartum glucocorticoid treatment for prevention of the respiratory distress syndrome in premature infants. Pediatrics, 50: 515 (1972).

25. Lovinger, R. D., Kaplan, S. L., and Grumbach, M. M.: Congenital hypopituitarism associated with neonatal hypoglycemia and microphallus: 4 cases secondary to hypothalamic hormone deficiences. J. Pediatr., 87: 1171 (1975).

26. Morris. M. G., Jorgensen, J. R., and Jenkins, S. A.: Plasma growth hormone concentration in corticosteroid treated children. J. Clin. Invest., 47: 427 (1968).

27. Motson, R. W.. Glass, D. N., Smith, D. A., and Daly, J. R.: The effect of shortand long-term corticosteroid treatment on sleep-associated growth hormone secretion. Clin. Endocrinol., 8: 314 (1978).

28. Murphy, B. E. P.: Some studies of the protein-binding of steroids and their application to the routine micro and ultramicro measurements of various steroids in body fluids by competitive protein-binding radioassay. J. Clin Endocrinol. Metab., 27: 973 (1967).

29. Nakagawa, K., Horiuchi, Y.. and Mashimo, K.: Further studies on the relation between growth hormone and corticotropin secretion in insulin-induced hypoglycemia. J. Clin. Endocrinol. Metab., 32: 188 (1971).

30. Negulescu, R. I., Strecker. J. R., Lauritzen, C., and Pal, S.: The influence of betamethasone on the feto-placental unit. A preliminary report. J. Perinat. Med., 5: 120 (1977).

31. Noguchi, A., Turnipseed, M. R., Bentley, K., and Reynolds, J. W.: Umbilical serum cortisol (F), dehydroepiandrosterone sulfate (DHAS), and total estriol $\left(E_{3}\right)$ levels in premature and full term infants. Pediat. Res. (Abstract), 12: 417 (1978).

32. Ohrlander, S., Gennser, G., Batra, S., and Lebech, P.: Effect of betamethasone administration on estrone, estradiol $17-\beta$, and progesterone in maternal plasma and amniotic fluid. Obstet. Gynecol., 49: 148 (1977).

33. Ohrlander, S., Gennser, Nilsson. K. O., and Eneroth. P.: ACTH test to neonates after administration of corticosteroids during gestation. Obstet. Gynecol., 49: 691 (1977).

34. Osathanondh, R., Tulchinsky, D., Kamali, H., Fencl, M. de M., and Taeusch, H. W. Jr. Dexamethasone levels in treated women and newborn infants. J. Pediatr. 90: 617 (1977)

35. Root, A. W., Bongiovanni, A. M., and Eberlein, W. R.: Studies on the secretion and metabolic effects of human growth hormone in children with glucocorticoid induced growth retardation. J. Pediatr., 75: 826 (1969).

36. Simmer, H. H., Tulchinsky, D., Gold, E. M., Frankland, M., Greipel, M., and Gold, A. S.: On the regulation of estrogen production by cortisol and ACTH in human pregnancy at term. Am. J. Obstet. Gynecol., 119: 283 (1974).

37. Strickland, A. L., Underwood, L. E., Voina, S. J., French, F. S., and Van Wyk, J. J.: Growth retardation in Cushing's syndrome. Am. J. Dis. Child., 123: 207 (1972).

38. Sybulski. S.: Effect of antepartum betamethasone treatment on cortisol levels in cord plasma, amniotic fluid, and the neonate. Am. J. Obstet. Gynecol., 127: 871 (1977).

39. Tait, J. F., and Burstein, S.: In vivo studies of steroid dynamics in man. In: G Pinkus, K. V. Thimann, and E. B. Astwood: The Hormones. Vol. 5. (Academic Press, Inc., New York, 1964) pp. 441-557.

40. Thornfeldt, R. E., Franklin, R. W., Pickering, N. A., Thornfeldt, C. R., and Amell. G.: The effect of glucocorticoids on the maturation of premature lung membranes. Am. J. Obstet. Gynecol. 131: 143 (1978).

41. von Werder, K.. Hane, S., and Forsham, P. H.: Suppression of hypothalamopituitary-adrenal axis and growth hormone release with dexamethasone. Horm. Metab. Res., 3: 171 (1971).

42. Winters, A. J., Colston, C., MacDonald, P. C., and Porter, J. C.: Fetal plasma prolactin levels. J. Clin. Endocrinol. Metab., 41: 626 (1975).

43. Youlton, R., Kaplan, S. L., and Grumbach, M. M.: Growth and growth hormone: IV. Limitations of the growth hormone response to insulin and arginine and of the immunoreactive insulin response to arginine in the assessment of growth hormone deficiency in children. Pediatrics, 43: 989 (1969).

44. We thank J. Carter, A. Jardiolin, and M. Solis for technical assistance, and R. A. Ballard of Mount Zion Hospital for providing samples of cord serum.

45. A preliminary report has been published in an abstract submitted to the Western Society for Pediatric Research (5).

46. Dr. Gluckman is recipient of a United States Public Health Service International Research Fellowship in Pediatric Endocrinology.

47. This research was supported by Pulmonary Specialized Center of Research HL19185 from the NHLBI and by grants from NICHD, NIAMDD, and Medical Research Council of New Zealand.

48. Requests for reprints should be addressed to: Philip L. Ballard, M. D., Department of Pediatrics, University of California, San Francisco, California 94143, USA.

49. Received for publication November 29, 1978.

50. Accepted for publication March 7, 1979. 